\title{
Corrigendum: New Insights on Leucine-Rich Repeats Receptor-Like Kinase Orthologous Relationships in Angiosperms
}

\author{
Jean-François Dufayard ${ }^{1}$, Mathilde Bettembourg ${ }^{1}$, Iris Fischer ${ }^{2}$, Gaetan Droc ${ }^{1}$, \\ Emmanuel Guiderdoni ${ }^{1}$, Christophe Périn ${ }^{1}$, Nathalie Chantret ${ }^{2 *}$ and Anne Diévart ${ }^{1 *}$ \\ ${ }^{1}$ CIRAD, UMR AGAP, Montpellier, France, ${ }^{2}$ INRA, UMR AGAP, Montpellier, France
}

\section{OPEN ACCESS}

Edited and reviewed by: Eduard Akhunov,

Kansas State University, United States

*Correspondence: Nathalie Chantret nathalie.chantret@inra.fr Anne Diévart

anne.dievart@cirad.fr

Specialty section: This article was submitted to Plant Genetics and Genomics, a section of the journal Frontiers in Plant Science

Received: 26 April 2017 Accepted: 15 May 2017 Published: 24 May 2017

Citation:

Dufayard J-F, Bettembourg M, Fischer I, Droc G, Guiderdoni E, Périn $C$, Chantret $N$ and Diévart $A$ (2017) Corrigendum: New Insights on Leucine-Rich Repeats Receptor-Like Kinase Orthologous Relationships in Angiosperms. Front. Plant Sci. 8:916. doi: 10.3389/fp/s.2017.00916
Keywords: LRR, receptor, kinase, angiosperms, phylogeny, orthologs

\section{A corrigendum on}

New Insights on Leucine-Rich Repeats Receptor-Like Kinase Orthologous Relationships in Angiosperms

by Dufayard, J.-F., Bettembourg, M., Fischer, I., Droc, G., Guiderdoni, E., Périn, C., et al. (2017). Front. Plant Sci. 8:381. doi: 10.3389/fpls.2017.00381

In the original article, the reference for the Prunus persica (PRUPE, peach) sequence genome was incorrectly written as (Ahmad et al., 2011). It should be (Verde et al., 2013). The authors apologize for this error and state that this does not change the scientific conclusions of the article in any way.

\section{REFERENCES}

\footnotetext{
Verde, I., Abbott, A.G., Scalabrin, S., Jung, S., Shu, S., Marroni, F., et al. (2013). The high quality draft genome of peach (Prunus persica) identifies unique patterns of genetic diversity, domestication and genome evolution. Nat. Genet. 45, 487-494. doi: $10.1038 /$ ng.2586
}

Conflict of Interest Statement: The authors declare that the research was conducted in the absence of any commercial or financial relationships that could be construed as a potential conflict of interest.

Copyright (c) 2017 Dufayard, Bettembourg, Fischer, Droc, Guiderdoni, Périn, Chantret and Diévart. This is an open-access article distributed under the terms of the Creative Commons Attribution License (CC BY). The use, distribution or reproduction in other forums is permitted, provided the original author(s) or licensor are credited and that the original publication in this journal is cited, in accordance with accepted academic practice. No use, distribution or reproduction is permitted which does not comply with these terms. 